Doi: HTTPS://DOI.ORG/10.23910/IJBSM/2017.8.5.1840a

\title{
Grafting in Brinjal (Solanum melongena L.) for Growth, Yield and Quality Attributes
}

\author{
B. Ashok Kumar ${ }^{*}$, A. K. Pandey ${ }^{2}$, P. Raja², Siddhartha Singh ${ }^{2}$ and L. Wangchu ${ }^{2}$
}

${ }^{1}$ Dept. of Vegetable Crops, Faculty of Horticulture, Bidhan Chandra Krishi Viswavidyalaya, Mohanpur, W. B. (741 252), India

${ }^{2}$ Dept. Vegetable Science, College of Horticulture \& Forestry (CAU), Pasighat, Arunachal Pradesh (791 102), India

\section{Corresponding Author}

B. Ashok Kumar

e-mail: ashokkumarcau@gmail.com

\author{
Article History \\ Article ID: AR1840a \\ Received in $2^{\text {nd }}$ September, 2017 \\ Received in revised form $24^{\text {th }}$ September, 2017 \\ Accepted in final form $6^{\text {th }}$ October, 2017
}

\begin{abstract}
The effect of different rootstocks on eggplant growth, fruit yield, and fruit quality were studied by comparing grafted plants with nongrafted ones under low cost polyhouse. The present investigation was carried out in the year, 2014-15, Experimental Farm, Department of Vegetable Science, College of Horticulture and Forestry (CAU) Pasighat. The experiment was laid out in Completely Randomised Design with 8 treatments (four wild Solanum species and two eggplant genotypes) and four replications. The seedlings of eggplant genotypes with pencil thickness were grafted with wild Solanum species by cleft method. The non-grafted plants were used as control. The highest survival rate observed in plants grafted with Solanum torvum followed by Solanum surathense. The plant morphology, reproductive and yield parameters were significantly affected by grafting. Control plants recorded minimum plant height with least number of leaves per plant. Furthermore, fruit weight, fruit yield, days to fruit maturity and rooting behaviour of plant were influenced positively by grafting. All grafted plants showed superior rooting and highest number, length, fresh weight and dry weight of roots were recorded in Solanum torvum followed by solanum khasianum. Based on mean performance, grafted plants of Solanum torvum and Solanum khasianum found to be superior for plant growth and yield attributing characters without effecting fruit quality. So, it can be concluded that grafting in eggplant is quite successful and alternate method of production.
\end{abstract}

Keywords: Eggplant, grafting, Solanum species, genotypes, growth, yield

\section{Introduction}

Eggplant (Solanum melongena L.) belongs to relatives of Solanaceae. Native to some parts of India or Indo-China, Vavilov (1951); Zeven and Zhukovsky (1975). India is the $2^{\text {nd }}$ largest producer of brinjal after China with 7.22 lack hectares and 13 lack tonnes of production (NHB, 2015). It occupies nearly $26 \%$ of the worldwide production.

Traditionally, grafting successful on woody perennials as a method to asexually propagated species that did not root well from vegetative cuttings. The grating in herbaceous vegetable crops started first in Japan, Korea and some European countries in the late $19^{\text {th }}$ century. Beginning from $20^{\text {th }}$ century, grafting technique used for production of vegetable crops, particularly famous in East Asia. The grafting involves tying a member of two plant parts (a rootstock and scion) from exclusive plant parts to shape a single, dwelling plant. Grafting in vegetable crops is a simple method of propagation where preferred rootstocks are used to set increased vigour, precocity, more yield and excellent and better survival under wide range of abiotic and biotic strain situations. Grafting reduced the dependency on chemical residues required to treat the soil borne diseases and opened new vista in sustainable production of vegetables. Grafting enhances water and nutrient uptake and nutrient use efficiency (Santa-Cruz et al., 2002), to extend the duration of harvest time and to improve fruit quality (Colla et al., 2006; Fernandez-Garcia et al., 2004). In addition innovations are mechanized and robot grafting has given a fillip to this novel eco-friendly method (Pandey and Rai, 2003). Semi-or fully automatic grafting robots have been invented with the aid of numerous agricultural industries inside the 1990's, but the models are restrained. The several commercial vegetable crops including eggplant tomato and watermelon are grafted to boom growth, yield, to induce resistance against biotic and abiotic stresses.

The grafting of eggplant started in the late 1950's by grafting onto wild Solanum rootstocks (Lee and Oda, 2003). The number of untamed Solanum species becomes reported as graft well matched to cultivated eggplant genotypes (Bletsos et al., 2003; Davis et al., 2008). Eggplant is widely cultivated in different climate conditions round the world is suitable to grafting (King et al., 2010). At present most cucurbits, tomato, eggplant and pepper leads in production. Grafting is an effective technology for use in mixture with more sustainable 
crop production practices, reducing the heavy use of chemicals and soil fumigants to manipulate soil borne pathogens.

Keeping these data in view, the prevailing experiment was planned to evaluate the graft compatibility of cultivated eggplant varieties onto wild Solanum species, to select suitable Solanum rootstock for eggplant grafting and to compare overall performance of grafted and non-grafted eggplant genotypes/varieties for yield and quality parameters inside the poly house conditions.

\section{Materials and Methods}

The present experiment was conducted at polyhouse complex, Experiment form, Department of Vegetable Science, College of Horticulture and Forestry (CAU), Pasighat, Arunachal Pradesh. The experimental design, Completely Randomised Design (CRD) with four replications inclusive of 5 plants for each replication. The experimental materials for the present study comprised of four wild Solanum species namely Solanum torvum, Solanum xanthocarpum, Solanum khasianum and Solanum surathense were used as rootstocks and two cultivated eggplant genotypes/varieties i.e. Pusa Shyamala (A) long fruited variety rich in anthocynin content in edible maturity stage and Pusa Hybrid-6(B) a round fruited early maturing variety were used as scion plants as shown in Table 1 and Plate 1 . The Seeds of wild Solanum species were sown in nursery beds on $5^{\text {th }}$ May, 2014. After 20 days

\begin{tabular}{ll}
\hline \multicolumn{2}{l}{ Table 1: Scion Rootstock combinations as treatments } \\
\hline Treatment no. & Treatment Combination \\
\hline $\mathrm{T}_{1}$ & Solanum torvum $\times$ Pusa Shyamala \\
$\mathrm{T}_{2}$ & Solanum torvum $\times$ Pusa Hybrid- 6 \\
$\mathrm{~T}_{3}$ & Solanum xanthocarpum $\times$ Pusa Shyamala \\
$\mathrm{T}_{4}$ & Solanum xanthocarpum $\times$ Pusa Hybrid-6 \\
$\mathrm{T}_{5}$ & Solanum khasianum $\times$ Pusa Shyamala \\
$\mathrm{T}_{6}$ & Solanum khasianum $\times$ Pusa Hybrid- 6 \\
$\mathrm{~T}_{7}$ & Solanum surathense $\times$ Pusa Shyamala \\
$\mathrm{T}_{8}$ & Solanum surathense $\times$ Pusa Hybrid- 6 \\
$\mathrm{~T}_{9}$ & control plants \\
\hline
\end{tabular}
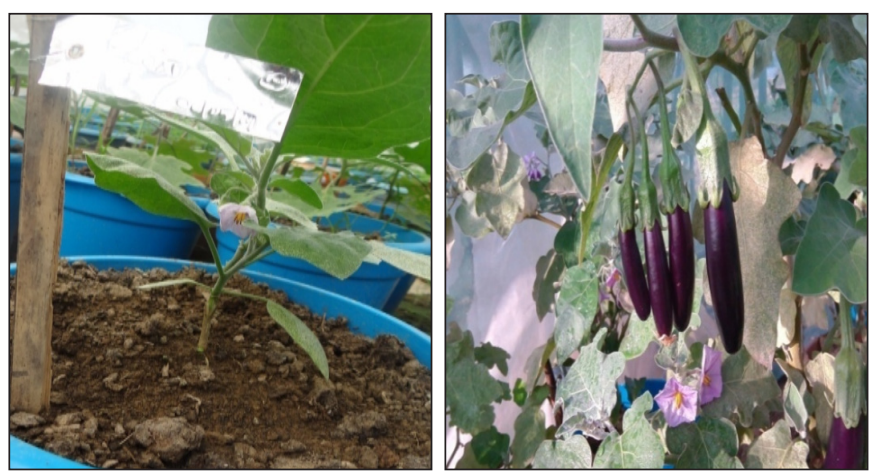

of germination, seedlings were transferred to plastic trays containing sandy soil with properly decomposed cow dung. The seeds of eggplant genotypes were sown in nursery beds on $25^{\text {th }}$ May, 2014. Before sowing, the seeds of each cultivated eggplant genotypes and wild Solanum species were dipped in $\mathrm{GA}_{3}$ solution (100 ppm) for $24 \mathrm{hrs}$ at room temperature for proper germination. The fifty days old rootstock seedlings having four to five leaves and seedlings of eggplant types with pencil thickness were selected for grafting. The cleft method of grafting was adopted while eggplant is herbaceous plant as shown in Lee and Oda, (2003) reports. All packages of practices were adopted uniformly as recommended for eggplant cultivation under greenhouse as per recommendations. The amount of nutrients distributed by fertigation, calculated on the basis of theoretical uptake, expected yields and mineral elements in soil.

The observations regarding graft survival rate was recorded 20 days after grafting (DAG). The morphological parameters like number of leaves plant ${ }^{-1}$ and plant height recorded 15 days interval from grafting, up to 60 days and final data taken for statistical analysis. The reproductive parameters especially days to first flowering, days required for fruit set to maturity were recorded from selected five plants from each replication. For fruit attributes five fruits were selected from each replication and used for measuring number of fruits, diameter of fruit, girth of fruit and fruit weight. The total fruit weight from each harvest taken for measuring fruit yield plant ${ }^{-1}$. The quality parameters especially TSS content and anthocynin content of fruit was analysed from freshly harvested fruits. The observations in relation to root parameters like number of roots per plant, length of roots, fresh weight and dry weight of roots were taken from five selected plants from each replication after final fruit harvest. The TSS content of fruits was measured by spectrophotometric method. Total anthocyanin content calculated according to a modification of the method described by Lee et al. (2005).

Statistical analysis: The data obtained were analysed by using analysis of variance for Completely Randomised design (CRD) as defined by Panse and Sukhatme, (1985). The level of significance used in F-test become 0.05 and critical difference (CD) values calculated each time. Statistical analysis has done using MSTAT-C.
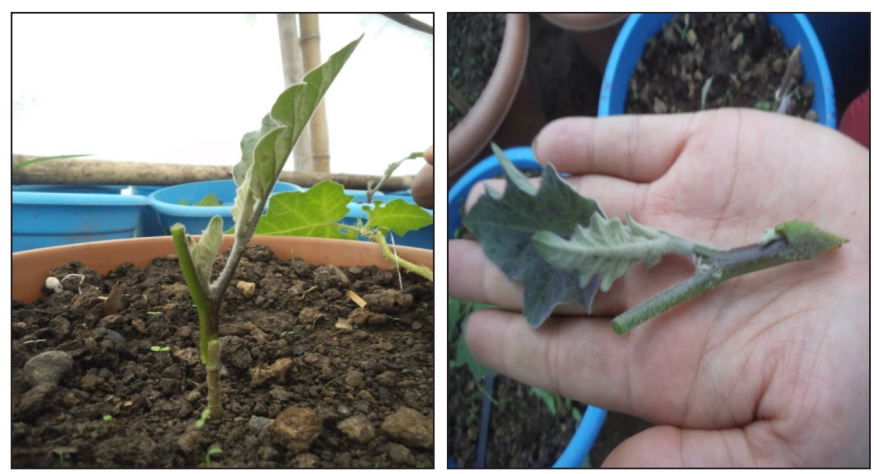

Plate 1: Effect of grafting on growth, reproductive and yield parameters of plants 


\section{Results and Discussion}

The graft compatibility study indicates that grafting of Pusa Hybrid-6 onto Solanum torvum rootstock had maximum survival rate $(67.5 \%)$ in comparison to all different graft combination as shown in the Table 2 . The lowest survival rate observed in Solanum xanthocarpum grafted with Pusa Shyamala (30\%). Maximum survival rate of grafted plants with Solanum torvum rootstock was sequel with the observations of Rahman et al. (2002); Oda et al. (2005); Petron and Hoover, (2014). The all four wild Solanum species will be suggested for grafting onto cultivated eggplant genotypes but except Solanum torvum remaining solanum species produces a low callus formation between rootstock and scion could lead to defoliation, reduction of scion growth and low survival rate.
The morphological parameters especially plant height, number of leaves and rooting behaviour of grafted plants were substantially better than non-grafted plant as shown in Table 2 and Plate 2. The maximum plant height mentioned in Solanum torvum grafted on Pusa Shyamala $(54.87 \mathrm{~cm})$ followed by Solanum khasianum onto Pusa Hybrid-6 (50.81) and the lowest observed in control plants. In the present study variable leaf number was observed during early growth period of plant. In addition Solanum torvum grafted with Pusa Shyamala had the highest number of leaves per plant whereas it was lowest in non-grafted plants. These effects of present findings are in agreement with the report of Bletsos, (2003) who found that grafted plants were taller and more vigorous than self-rooted plants. As recorded by Yetisir et al. (2007)

\begin{tabular}{lccccccc}
\hline \multicolumn{7}{l}{ Table 2: Effect of grafting on survival rate and morphological parameters of eggplant } \\
\hline $\begin{array}{l}\text { Treatment } \\
\text { combination }\end{array}$ & $\begin{array}{c}\text { Survival rate } \\
\text { (\%) }\end{array}$ & $\begin{array}{c}\text { Plant height } \\
(\mathrm{cm})\end{array}$ & $\begin{array}{c}\text { Number of } \\
\text { leaves plant }^{-1}\end{array}$ & $\begin{array}{c}\text { No. of primary } \\
\text { roots plant }^{-1}\end{array}$ & $\begin{array}{c}\text { Length of } \\
\text { roots (cm) }\end{array}$ & $\begin{array}{c}\text { Fresh weight } \\
\text { of roots (g) }\end{array}$ & $\begin{array}{c}\text { Dry weight } \\
\text { of roots (g) }\end{array}$ \\
\hline $\mathrm{T}_{1}$ & 66.575 & 54.875 & 24.000 & 14.5 & 56.500 & 20.125 & 17.750 \\
$\mathrm{~T}_{2}$ & 67.35 & 53.375 & 22.25 & 14.75 & 49.875 & 20.125 & 18.500 \\
$\mathrm{~T}_{3}$ & 30.025 & 40.125 & 23.750 & 8.37 & 35.375 & 12.000 & 10.375 \\
$\mathrm{~T}_{4}$ & 30.15 & 41.500 & 19.625 & 7.25 & 38.000 & 12.500 & 10.850 \\
$\mathrm{~T}_{5}$ & 40.3 & 50.813 & 19.37 & 11 & 46.125 & 16.625 & 14.750 \\
$\mathrm{~T}_{6}$ & 39.225 & 50.000 & 20.75 & 11.62 & 44.250 & 14.125 & 12.875 \\
$\mathrm{~T}_{7}$ & 53.5 & 49.250 & 19.875 & 9.75 & 38.625 & 15.875 & 14.250 \\
$\mathrm{~T}_{8}$ & 49.675 & 49.625 & 19.000 & 10.75 & 35.375 & 13.500 & 11.500 \\
$\mathrm{~T}_{9}$ & - & 31.750 & 18.375 & 11.75 & 22.500 & 15.750 & 12.250 \\
$\mathrm{CD}(p=0.05)$ & 4.508 & 8.021 & 3.772 & 3.155 & 14.713 & 5.473 & 5.157 \\
$\mathrm{SEd} \pm$ & 2.183 & 3.9 & 1.838 & 1.537 & 7.167 & 2.666 & 2.513 \\
\hline
\end{tabular}
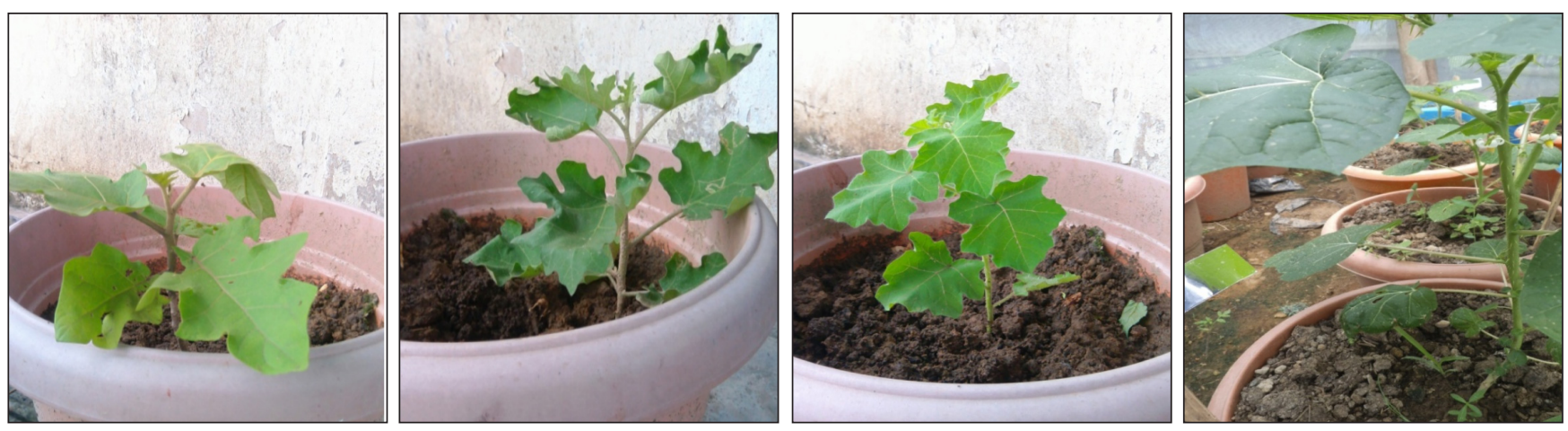

Plate 2: Seedlings of wild solanum species before grafting

all grafted plants of watermelon showed a higher number of leaves and greater dry weight than the non-grafted control plants. The grafting enhanced root system of plants resulting in vigorous growth and increased production. The formation of graft union and interaction between rootstock and scion influences root system of plant. In present study, irrespective of scion either Pusa Shyamala or Pusa Hybrid-6, rootstock

Solanum torvum expressed maximum number of roots, their length, fresh weight and dry weight which is shown in table 2 and Plate 3. Further all grafted plants had maximum root length as compared to non-grafted plants is in line with the report of Alan et al. (2007); Bletsos (2005) who reported that grafted plants are vigorous, absorbs more nutrients which are attributed through deep tap rooted system. 

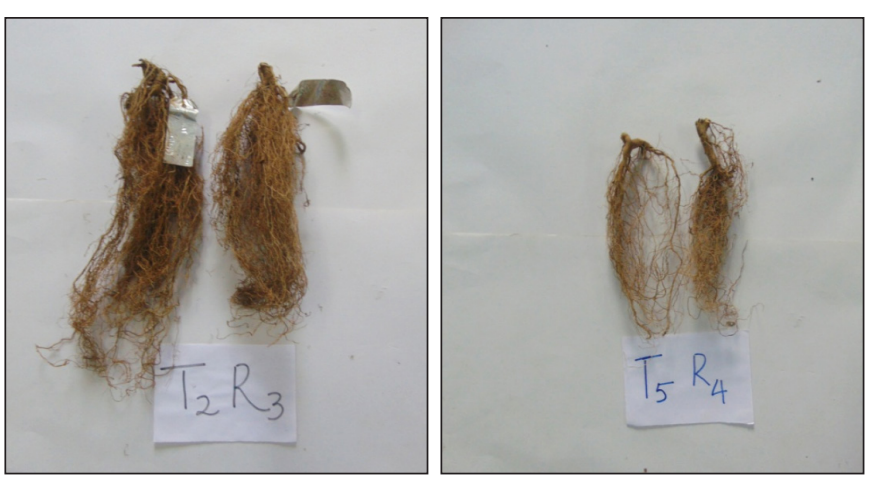

Plate 3: Effect of grafting on rooting behaviour of plants

The data related to days required for flowering, fruit set to maturity, yield parameters and quality characters recorded in Table 3 were significant to each other. The all grafted and non-grafted plants commenced flowering within 50 to 70 days after seed sowing. It was commonly observed that nongrafted plants were bloomed in advance than grafted ones. The flowering observed late in Pusa Hybrid-6 grafted onto Solanum xanthocarpum followed by Pusa Shyamala grafted
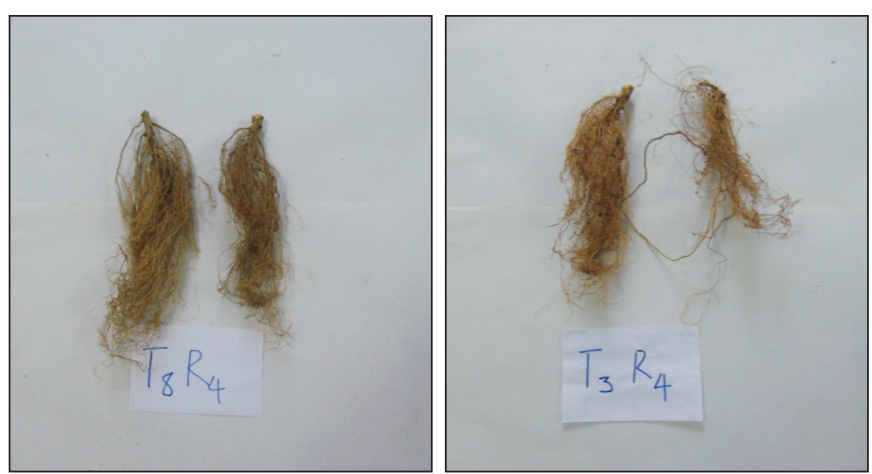

onto Solanum khasianum. In grafted plants the formation of graft union between scion and rootstock necessary to translocate food material from root system to apical parts of plant and leads the delayed flowering in grafted plants. Comparable consequences for delayed flowering in grafted plants of eggplant had been mentioned by Suthar et al. (2005). The lowest days for fruit setting to maturity (19.31 days) required in plants of Solanum torvum grafted onto Pusa

\begin{tabular}{|c|c|c|c|c|c|c|c|}
\hline $\begin{array}{l}\text { Treatment } \\
\text { combination }\end{array}$ & $\begin{array}{c}\text { Days required } \\
\text { for flowering }\end{array}$ & $\begin{array}{c}\text { Days required } \\
\text { for fruit set to } \\
\text { maturity }\end{array}$ & $\begin{array}{l}\text { No. fruits } \\
\text { plant }^{-1}\end{array}$ & $\begin{array}{l}\text { Individual } \\
\text { fruit weight } \\
\text { (g) }\end{array}$ & $\begin{array}{l}\text { Fruit yield } \\
\left(\text { kg plant }^{-1}\right)\end{array}$ & TSS ( ${ }^{\circ}$ Brix) & 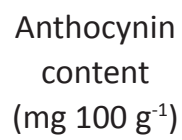 \\
\hline $\mathrm{T}_{1}$ & 39.425 & 19.313 & 19.375 & 61.813 & 1.234 & 3.730 & 0.419 \\
\hline$T_{2}$ & 39.875 & 20.938 & $20 a$ & 64.25 & 1.323 & 4.023 & 0.411 \\
\hline$T_{3}$ & 44.375 & 23.813 & 14.125 & 53.5 & 0.757 & 3.515 & 0.398 \\
\hline $\mathrm{T}_{4}$ & 46.375 & 23.375 & 14.375 & 53.25 & 0.765 & 3.823 & 0.409 \\
\hline$T_{5}$ & 43.463 & 22.375 & 15.625 & 59.813 & 0.956 & 3.620 & 0.407 \\
\hline$T_{6}$ & 41.875 & 23.438 & 15 & 61.188 & 0.925 & 3.898 & 0.389 \\
\hline $\mathrm{T}_{7}$ & 37.875 & 21.938 & 15 & 61.25 & 0.942 & 3.610 & 0.397 \\
\hline $\mathrm{T}_{8}$ & 41.000 & 23.813 & 16.25 & 60.5 & 1.007 & 3.863 & 0.406 \\
\hline $\mathrm{T}_{9}$ & 34.625 & 24.87 & 11.125 & 50.563 & 0.566 & 4.158 & 0.415 \\
\hline $\mathrm{CD}(p=0.05)$ & 5.858 & 2.428 & 1.958 & 6.199 & 0.159 & 0.248 & NS \\
\hline SEd \pm & 2.853 & 1.183 & 0.954 & 3.02 & 0.077 & 0.137 & \\
\hline
\end{tabular}

Shyamala. Non-grafted plants required maximum number of days ( 24.87 days) followed by Solanum surathense grafted onto Pusa Hybrid-6 required (23.81 days) for fruit setting to maturity. In present findings the plants grafted onto Solanum torvum gave highest number of fruits where as non-grafted plants produced lowest number of fruit.

The considerable differences observed in grafted and nongrafted plants with respect to average fruit weight of individual fruits whereas highest obtained in grafted plants of Solanum torvum with Pusa Shyamala (64.25 g) followed by Solanum torvum grafted onto Pusa Hybrid-6 (61.81 g) and lowest obtained in control plants $(50.563 \mathrm{~g})$. The results indicates that grafted plants produced appreciably early in fruit production than control. The grafted plants onto Solanum torvum had highest fruit yield per plant $\left(1.323 \mathrm{~kg} \mathrm{plant}^{-1}\right)$ followed by Pusa Hybrid-6 grafted onto solanum surathense (1.007 kg plant $^{-1}$ ) and the lowest fruit yield plant ${ }^{-1}$ was recorded in non-grafted plants $\left(0.566 \mathrm{~kg} \mathrm{plant}^{-1}\right)$. Chetelat and Peterson, (2003) also observed comparable consequences in respect to fruit yield plant ${ }^{-1}$. There have been great differences observed among grafted and non-grafted plants regarding TSS content ('Brix). The result indicates that TSS content of fruit was not significantly affected by grafting. The maximum TSS content recorded in non-grafted plants, $\left(4.15^{\circ} \mathrm{Brix}\right)$ and followed by Solanum torvum $\times$ Pusa Hybrid -6 ( $4.02^{\circ} \mathrm{Brix}$ ) and lowest was recorded in Solanum xanthocarpum $\times$ Pusa Shyamala, (3.51 
$\left.{ }^{\circ} \mathrm{Brix}\right)$. These findings are in agreement with the observations of Turhan et al. (2011); Bletsos (2003). There were not significant results obtained for anthocynin content in grafted and non-grafted plants whereas highest obtained in Solanum torvum grafted with Pusa Shyamala (0.419 mg $\left.100 \mathrm{~g}^{-1}\right)$ and lowest obtained in Solanum khasianum $\times$ Pusa Hybrid-6.

The influence of grafting also found on fruit length, girth and circumference as shown in Table 4. In long fruited variety the maximum fruit length observed in fruits of Solanum torvum $\times$ Pusa Shyamala $(11.25 \mathrm{~cm})$ and followed by Solanum khasianum grafted onto Pusa Shyamala (9.94

Table 4: Effect of grafting on fruits parameters of long and round fruited varieties of eggplant

\begin{tabular}{llccc}
\hline Variety & $\begin{array}{l}\text { Treatment } \\
\text { combina- } \\
\text { tion }\end{array}$ & $\begin{array}{c}\text { Length } \\
\text { of fruits } \\
(\mathrm{cm})\end{array}$ & $\begin{array}{c}\text { Diameter } \\
\text { of fruit } \\
(\mathrm{cm})\end{array}$ & $\begin{array}{c}\text { Circumfer- } \\
\text { ence of } \\
\text { fruits }(\mathrm{cm})\end{array}$ \\
\hline Long fruit- & T×A & 11.255 & 3.555 & 11.125 \\
ed variety & $\mathrm{X} \times \mathrm{A}$ & 9.730 & 2.690 & 8.365 \\
& $\mathrm{~K} \times \mathrm{A}$ & 9.940 & 2.710 & 8.973 \\
$\mathrm{~S} \times \mathrm{A}$ & 9.090 & 3.303 & 10.365 \\
$\mathrm{CD}$ & 1.745 & 0.342 & 0.955 \\
$(p=0.05)$ & & & \\
$\mathrm{SED}$ & 0.8 & 0.156 & 0.438 \\
$\mathrm{~T} \times \mathrm{B}$ & 5.718 & 4.923 & 15.273 \\
$\mathrm{X} \times \mathrm{A}$ & 4.485 & 4.205 & 12.368 \\
$\mathrm{~K} \times \mathrm{A}$ & 4.248 & 3.610 & 11.943 \\
$\mathrm{~S} \times \mathrm{A}$ & 6.028 & 4.410 & 13.798 \\
$\mathrm{CD}$ & 0.621 & 0.440 & 1.644 \\
$(p=0.05)$ & & & \\
$\mathrm{SEd} \pm$ & 0.284 & 0.201 & 0.754 \\
\hline & & & \\
\hline
\end{tabular}

$\mathrm{cm})$. The highest diameter recorded in fruits of Solanum torvum grafted with Pusa Shyamala $(3.55 \mathrm{~cm})$ and follows Solanum surathensexPusa Shyamala $(3.3 \mathrm{~cm})$. The highest circumference recorded in Solanum torvum grafted with Pusa Shyamala $(11.12 \mathrm{~cm})$ followed by Solanum khasianum grafted onto Pusa Shyamala $(10.36 \mathrm{~cm})$. In spherical fruited variety the maximum fruit length observed in Solanum surathensexPusa Hybrid-6 $(6.02 \mathrm{~cm})$ and followed by Solanum torvum grafted with Pusa Hybrid-6 $(5.71 \mathrm{~cm})$. The highest diameter recorded in fruits of Solanum torvum grafted with Pusa Hybrid-6 (4.92 $\mathrm{cm}$ ) and follows Solanum surathensexPusa Hybrid-6 (4.41 $\mathrm{cm})$. The highest circumference recorded in Solanum torvum grafted with Pusa Hybrid-6 $(15.27 \mathrm{~cm})$ followed by Solanum surathense grafted onto Pusa Shyamala $(13.79 \mathrm{~cm})$. The maximum number, length, diameter, and circumference of fruits were obtained from the plants grafted onto Solanum torvum either with Pusa Shyamala or Pusa Hybrid-6 and it might be due to compatibility of rootstock with cultivated genotypes leads good vigor. These consequences are agreement with observations of Aloni et al. (2010) who marked rootstock impacts on number of fruits, fruit length and diameter.

\section{Conclusion}

Among all rootstocks used in grafting, Solanum torvum showed promising for yield and yield attributing characters. The study can be extended to wide variety of eggplant cultivars with more wild species to monitor the different quantitative and qualitative traits of yield attributing characters in precise way.

\section{Acknowledgement}

The authors show gratitude to Department of Vegetable Science, College of Horticulture and Forestry (CAU) Pasighat, A.P., India for their financial and technical support to accomplish research work.

\section{Reference}

Alan, O., Ozdemir, N., Gunen, Y., 2007. Effect of grafting on watermelon plant growth, yield and quality. Journal of Agronomy 6(2), 362-365.

Aloni, B., Cohen, R., Kami, L., Aktas, H., Edelstein, M., 2010. Hormonal signaling in rootstock-scion interactions. Scientia Horticulturae 127, 119-126.

Bletsos, F., 2003. Effect of grafting on growth, yield and Verticillium wilt of eggplant. Journal of Horticulture Science 38(2), 183-186.

Bletsos, F., Thanassoulopoulos, C., Roupakias, D., 2003. Effect of grafting on growth, yield, and Verticillium wilt of eggplant. Hortscience 38, 183-186.

Bletsos, F., 2005. Use of grafting and calcium cyanamide as alternatives to methyl bromide soil fumigation and their effects on growth, yield, quality and fusarium wilt control in melon. Journal of Phytopathology 153, 155-161.

Chetelat, R.T., Petersen, J., 2003. Improved maintenance of the tomato like Solanum species by grafting. TGC 53, 14.

Colla, G., Rouphael, Y., Cardarelli, M., Massa, D., Salerno, A., Rea, E., 2006. Yield, fruit quality and mineral composition of grafted melon plants grown under saline conditions. Journal of Horticultural Science and Biotechnology 81, 146-152.

Davis, A.R., Perkins-Veazie, P., Sakata, Y., Lopez-Galarza, S., Maroto, J.V., Lee, S.G., Huh, Y.C., Sun, Z., Miguel, A., King, S.R., Cohen, R., Lee, J.M., 2008. Cucurbit grafting. Critical Reviews in Plant Sciences 27, 50-74.

Fernandez-Garcia, N., Martinez, V., Carvajal, M., 2004. Effect of salinity on growth, mineral composition, and water relations of grafted tomato plants. Journal of Plant Nutrition and Soil Science 167, 616-622.

NHB, 2015. Indian Horticulture Data Bases, HQ, Gurgaon, Haryana.

King, S.R., Davis, A.R., Zhang, X., Crosby, K., 2010. Genetics, breeding and selection of rootstocks for Solanaceae and 
Cucurbitaceae. Scientia Horticulturae 127, 106-111.

Lee, J.M., Oda, M., 2003. Grafting of herbaceous vegetable and ornamental crops. Horticultural Reviews 28, 61-124.

Lee, J.M., Durst, R.W., Wrolstad, R.E., 2005. Determination of total monomeric anthocyanin pigment content of fruit juices, beverages, natural colorants, and wines by the $\mathrm{pH}$ differential method: collaborative study. Journal of AOAC International 88, 1269-1278.

Oda, M., Maruyama, M., Mori, G., 2005. Water transfer at graft union of tomato plants grafted onto Solanum rootstocks. Journal of Japanese Society Horticultural Science 74, 458-463.

Pandey, A.K., Rai, M., 2003. Prospects of grafting in vegetables: an appraisal. Vegetable Science 30(2), 101-109.

Panse, V.G., Sukhatme, P.V., 1985. Statistical Methods for Agricultural Workers. Indian Council of Agricultural Research, New Delhi, India, 359.

Petran, A., Hoover, E., 2014. Solanum torvum as a compatible rootstock in inter specific tomato grafting. Journal of Horticulture 1(1), 103.

Rahman, M.A., Rashid, M.A., Husain, M.M., Salam, M.A., Mason, A.S.M.H., 2002. Grafting compatibility of cultivated eggplant varieties with wild Solanum species. Pakistan Journal of Biological Sciences 5(7), 75-757.
Santa-Cruz, A., Martinez-Rodriguez, M.M., Perez-Alfocea, F., Romero-Aranda, R., Bolarin, M.C., 2002. The rootstock effect on the tomato salinity response depends on the shoot genotype. Plant Sciences 162, 825-831.

Suthar, M.R., Singh, G.P., Rana, M.K., Makhan, L., 2005. Growth and fruit yield of brinjal (Solanum melongena L.) as influenced by planting dates and fertility levels. Crop Research Journal 30(1), 77-79.

Turhan, A., Ozmen, N., Serbrci, M.S., Seniz, V., 2011. Effects of grafting on different rootstocks on tomato fruit yield and quality. Horticultural Sciences 38, 142-149.

Vavilov, N.I., 1951. The origin, variation, immunity and breeding of cultivated plants. Chronica Botanica 13, 1-364.

Yetisir, H., Kurt, F., Sari, N., Tok, F.M., 2007. Rootstock potential of Turkish Lagenaria siceraria germplasm for watermelon: plant growth, graft compatibility, and resistance to Fusarium. Turkish Journal of Agriculture and Forestry 31, 381-388.

Zeven, A.C., Zhukovsky, P.M., 1975. Dictionary of cultivated plants and their centres of diversity. Centre for Agricultural Publishing and Documentation, Wegeningen, Netherlands. 